\title{
GOOGLE APPS FOR EDUCATION (GAFE) DEMI PENINGKATAN KUALITAS PEMBELAJARAN ERA DIGITAL DI SMK DAR-EL HIKMAH PEKANBARU
}

\author{
Melly Novalia*, Edi Ismanto, Vitriani, Resmi Darni, Rahmad Alrian, \\ Pratama Benny Herlandi \\ Program Studi Pendidikan Informatika, Fakultas Keguruan dan Ilmu Pendidikan \\ Universitas Muhammadiyah Riau \\ email: mellynovalia@umri.ac.id
}

\begin{abstract}
The dedication to the community aims to provide training to all teachers at SMK Dar-el Hikmah Pekanbaru on the utilization of Google Apps for Education (GAFE) as a instructional medium in schools. The service method was conducted with training and evaluated regularly with the guidance of instructors from the Informatics Education Lecturer Team. As a result, all trainees get new knowledge about GAFE content such as Google Classroom, Google Form, Google Calendar and Google Drive. And also the school, hopes that there will be further training on developing the interactive instructional media.
\end{abstract}

Keywords: Google Apps for Education (GAFE), instructional media

\section{Abstrak}

Pengabdian kepada masyarakat bertujuan untuk memberikan pelatihan kepada seluruh guru SMK Dar-el Hikmah Pekanbaru tentang pemanfaatan Google Apps for Education (GAFE) sebagai media pembelajaran di sekolah. Metode pengabdian dilakukan dengan pelatihan dan dievaluasi secara berkala dengan bimbingan instruktur dari Tim Dosen Pendidikan Informatika. Hasilnya seluruh peserta pelatihan dapat memanfaatkan berbagai konten GAFE seperti Google Classroom, Google Form, Google Calendar dan Google Drive dan pihak sekolah juga berharap akan ada pelatihan selanjutnya tentang pengembangan media pembelajaran mutakhir dan interaktif sesuai tuntutan zaman sekarang.

Kata kunci: Google Apps for Education (GAFE), media pembelajaran

\section{PENDAHULUAN}

Perkembangan teknologi informasi dan komunikasi sangat mempengaruhi segala aspek kehidupan di masyarakat, termasuk aspek pendidikan. Teknologi informasi dan komunikasi dalam bidang pendidikan dapat berperan ganda yaitu sebagai media atau alat bantu pembelajaran dan sebagai bahan atau materi pembelajaran bagi peserta didik. Berdasarkan hal tersebut, maka pendidikan sangat erat kaitannya dan berperan penting dalam perkembangan teknologi informasi dan komunikasi.
Arah perkembangan teknologi informasi dan komunikasi saat ini lebih fokus terhadap teknologi komputerisasi, melibatkan jaringan internet dan serba digital. Untuk itu, pendidikan juga harus bertransformasi dari konvensional menuju teknologi informasi dan komunikasi digital. Jika pendidikan tidak mengikuti arus ini, maka dikhawatirkan akan sangat tertinggal dan tentunya berdampak pada kualitas pendidikan.

Jumlah materi yang disampaikan kepada peserta didik berbanding lurus 
dengan waktu yang diperlukan. Artinya semakin banyak materi yang harus dikuasai peserta didik, maka semakin banyak pula waktu yang dibutuhkan guru untuk menyampaikannya. Sementara waktu yang dialokasikan pada jam pelajaran di sekolah sangat terbatas. Untuk itu pemanfaatan media berbasis teknologi digital sangat dibutuhkan untuk memfasilitasi keterbatasan tersebut.

Guru era sekarang tidak boleh menyiakan produk yang telah digratiskan oleh perusahaan perangkat lunak tersebut. Sebaliknya, guru harus semaksimal mungkin memanfaatkan seluruh fasilitas yang disediakan dalam bentuk berbagai aplikasi untuk edukasi. Hal ini dilakukan demi peningkatan kualitas pembelajaran yang lebih baik.

Sekolah Menengah Kejuruan (SMK) Dar-El Hikmah adalah lembaga pendidikan dan latihan yang berada dibawah naungan Yayasan Nur Iman Pekanbaru berbasis Pondok Pesantren, dengan jumlah siswa 80 orang dan jumlah guru sebanyak 19 orang. Lokasi sekolah berada di Jalan Manyar Sakti Km. 12 Simpang Baru, Kecamatan Tampan Pekanbaru. Adapun misi SMK Dar-El Hikmah adalah:

1. Memanfaatkan dan mengembangkan keunggulan teknologi modern guna mendorong kreativitas siswa untuk belajar.

2. Menghayati dan mengamalkan ajaran islam yang berdasarkan alquran dan hadits secara murni dalam kehidupan sehari hari

3. Meningkatkan kompetensi guru dan siswa dalam penguasaan IMTAQ dan IPTEK sehingga menghasilkan tamatan yang memiliki keterampilan dan mampu bersaing di tingkat global.

Berdasarkan misi ini, khususnya poin pertama dan ketiga, pengenalan dan pelatihan aplikasi berbasis teknologi informasi dan komunikasi merupakan salah satu wadah yang dapat memenuhi pencapaian misi tersebut.

Ketersediaan aplikasi atau perangkat lunak sebagai media pembelajaran saat ini banyak di pasaran, baik gratis maupun berbayar. Sebagai guru era sekarang, perlu memanfaatkan media atau aplikasi demi peningkatan kualitas pembelajaran. Salah satu perusahaan perangkat lunak yang tanggap dan menyediakan berbagai aplikasi untuk mengakomodasi kebutuhan pendidikan era sekarang adalah Google. Google menawarkan sebuah aplikasi bernama Google Apps For Education (GAFE), yaitu sebuah aplikasi gratis yang disediakan bagi lembaga pendidikan dengan teknologi informasi, komunikasi dan kolaborasi. Fasilitas atau produk GAFE mencakup Gmail, Classroom, Drive, Docs, Slides, Form dan Sheet.

Berdasarkan hasil observasi dan wawancara dengan Wakil Kepala Sekolah Bidang Kurikulum, bahwa sebagian besar guru SMK Dar-el Hikmah Pekanbaru masih terbatas keterampilannya dalam menggunakan perangkat atau media pembelajaran berbasis teknologi informasi dan komunikasi (TIK). Salah satu penyebabnya adalah kurangnya pelatihan yang diselenggarakan sekolah bagi guru khususnya materi tentang pengembangan media pembelajaran berbasis TIK.

Berdasarkan permasalahan mitra, maka dosen program studi Pendidikan Informatika Fakultas Keguruan dan Ilmu Pendidikan Universitas Muhammadiyah Riau memberikan solusi dengan memberikan pelatihan kepada seluruh guru di SMK Da-rel Hikmah Pekanbaru tentang pemanfaatan Google Apps for Education (GAFE) sebagai media pembelajaran di sekolah.

Luaran dari pelaksanaan


pengabdian kepada masyarakat di SMK Dar-el Hikmah Pekanbaru adalah peningkatan kompetensi profesional guru yaitu dapat mengembangkan media pembelajaran beserta perangkat lainnya dengan memanfaatkan Google Apps for Education (GAFE). Ditandai dengan seluruh guru telah memanfaatkan $G A F E$ sebagai kelas digital atau sarana pendukung pembelajaran untuk setiap mata pelajaran dan kelas yang diampu.

\section{METODE PENGABDIAN}

Kegiatan yang dilakukan dalam pengabdian kepada masyarakat ini adalah memberikan pelatihan kepada peserta pelatihan yaitu seluruh pendidik SMK Dar-El Hikmah dengan metode ceramah dan presentasi tentang produk Google Apps for Education (GAFE) yaitu Gmail, Classroom, Drive, Docs, Slides, Form dan Sheet. Dilanjutkan dengan demonstrasi tutorial/cara menggunakan produk-produk GAFE serta dipraktekkan langsung oleh peserta pelatihan dengan bimbingan instruktur.

\section{HASIL DAN PEMBAHASAN}

Pelatihan Google Apps For Education (GAFE) di SMK Dar-El Hikmah Pekanbaru berhasil dilaksanakan pada Sabtu, 8 September 2018. Jumlah peserta hadir sebanyak 11 orang dari total jumlah guru 19 orang. Guru yang berhalangan hadir karena beberapa alasan, yaitu bertepatan dengan jadwal mengajar, sakit dan izin menghadiri acara keluarga. Walau dengan jumlah peserta yang kurang maksimal, namun antusias peserta dapat dirasakan mulai dari awal hingga akhir pelatihan. Rincian peserta workshop dapat dilihat pada gambar 1 .

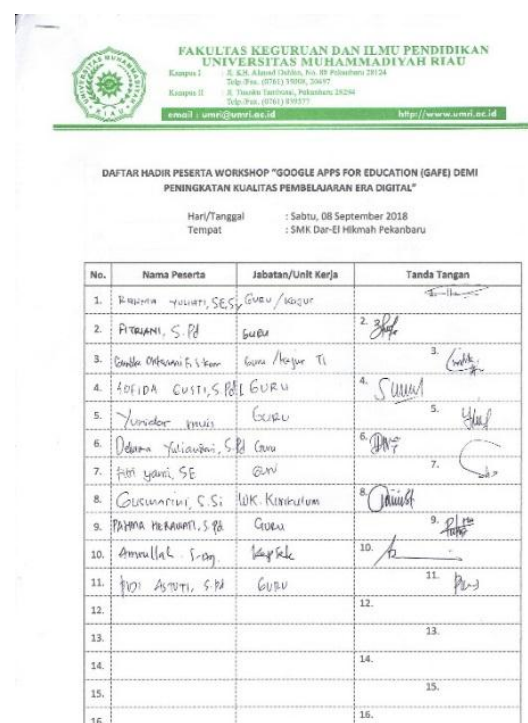

Gambar 1. Daftar Hadir Peserta

Pelatihan juga dihadiri oleh Pimpinan Fakultas Keguruan dan Ilmu Pendidikan (FKIP), Ketua Program Studi Pendidikan Informatika, Kepala Sekolah SMK Dar-el Hikmah Pekanbaru, dan seluruh dosen Pendidikan Informatika. Adapun susunan acara pelatihan adalah:

1. Pembukaan oleh MC

2. Pembacaan ayat suci Al-qur'an

3. Sambutan Kepala Sekolah SMK Dar-el Pekanbaru

4. Sambutan Dekan (FKIP)

5. Workshop Google Apps For Education (GAFE)

6. Foto bersama

7. Penutup

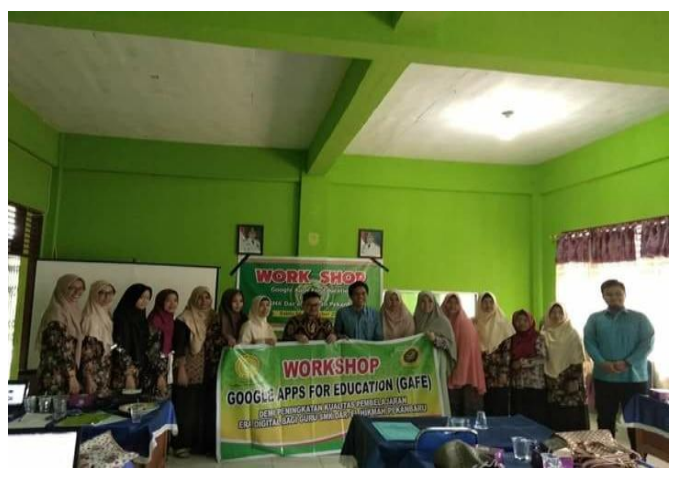

Gambar 2. Kegiatan Pengabdian

Kegiatan pelatihan dimulai dengan pemaparan materi Google Apps For 
Education (GAFE) tentang pengenalan aplikasi GAFE, konten GAFE, demonstrasi dan tutorial dari instruktur tentang pengunaan beberapa aplikasi GAFE seperti Google Classroom, Calendar, Google Drive, dan lain-lain. Selanjutnya seluruh peserta pelatihan mempraktekkannya pada laptop masingmasing dengan bimbingan instruktur yaitu dosen-dosen Pendidikan Informatika. Masing-masing peserta membuat Google Classroom sesuai dengan mata pelajaran yang mereka ampu.

Hasil kegiatan ini antara lain:

a. Peserta pelatihan dapat memahami kegunaan dan manfaat berbagai aplikasi $G A F E$

b. Peserta pelatihan dapat membuat sebuah kelas digital pada aplikasi GAFE (Google Classroom)

c. Peserta dapat menggunakan Google Form, Google Calendar dan Google Drive

Selain pengetahuan atau informasi baru yang diperoleh, peserta pelatihan mendapatkan keterampilan baru dalam mengembangkan media pembelajaran, sehingga mereka sangat senang dan berharap akan ada kegiatan sejenis di kesempatan yang akan datang. Mereka berharap dosen Pendidikan Informatika merencanakan kembali untuk memberikan dan membagi ilmu terkait cara mengembangkan media pembelajaran mutakhir dan interaktif sesuai tuntutan zaman sekarang.

Kelanjutan dari kegiatan pengadian kepada masyarakat ini, yaitu beberapa bulan ke depan, kembali tim dosen Pendidikan Informatika akan mengevaluasi hasil kegiatan, seperti memastikan seluruh peserta pelatihan masih memanfaatkan GAFE sebagai media pembelajaran atau sebaliknya. Harapannya, seluruh peserta pelatihan yaitu Guru SMK Dar-el Hikmah Pekanbaru, masih tetap menggunakan dan mengembangkan pada mata pelajaran lainnya. Namun jika ternyata ada kendala, tim dosen akan berusaha mencari solusinya.

\section{SIMPULAN}

Dari kegiatan pelatihan Google Apps For Education di SMK Dar-El Hikmah Pekanbaru, disimpulkan bahwa:

1. Pihak sekolah sangat mengapresiasi kegiatan pelatihan sebagai wujud pengabdian kepada masyarakat dosen Pendidikan Informatika Fakultas Keguruan dan Ilmu Pendidikan UMRI

2. Seluruh peserta pelatihan yaitu guruguru SMK Dar-El Hikmah Pekanbaru mendapatkan pengetahuan dan keterampilan baru tentang pemanfaatan $G A F E$ sebagai media pembelajaran dan komunikasi bagi peserta didik

3. Peserta pelatihan berharap akan ada pelatihan selanjutnya tentang pengembangan media pembelajaran mutakhir dan interaktif sesuai tuntutan zaman sekarang

4. Kepala Sekolah SMK Dar-El Hikmah Pekanbaru berharap tim dosen Pendidikan Informatika mengevaluasi kegiatan pengabdian ini pada bulan selanjutnya.

\section{UCAPAN TERIMA KASIH}

Terlaksananya pengabdian kepada masyarakat ini tidak lepas dari peran berbagai pihak, untuk itu penulis menghaturkan terima kasih kepada:

1. Rektor UMRI

2. Ketua LPPM UMRI

3. Dekan FKIP UMRI

4. Ketua Program Studi FKIP UMRI

5. Kepala Sekolah SMK Dar-El Hikmah Pekanbaru

6. Majelis guru SMK Dar-El Hikmah Pekanbaru 


\section{DAFTAR PUSTAKA}

[1] Chris Carey, et al. (2007). An Educator's Guide to Google Apps for Education. FTC Publishing

[2] Deni Darmawan. (2013). Pendidikan Teknologi Informasi dan Komunikasi. Bandung: Remaja Rosdakarya

[3] Kyle Brumbaugh, et. al. (2014). Creating a Google Apps Classroom: The Educator's Cookbook. Huntington Beach: Sheel Educational Publishing

[4] Rusman, dkk. (2011). Pembelajaran Berbasis Teknologi Informasi dan Komunikasi. Jakarta: Raja Grafindo Persada

[5] Rusman. (2009). Manajemen Kurikulum: Seri Manajemen Sekolah Bermutu. Jakarta: Raja Grafindo Persada 